\title{
PROBLEMATIC PHOSPHATIC PLATES FROM THE SILURIAN-EARLY DEVONIAN OF BOHEMIA, CZECH REPUBLIC
}

\author{
ANNALISA FERRETTI, ${ }^{1}$ ENRICO SERPAGLI, ${ }^{1}$ AND PETR ŠTORCH ${ }^{2}$ \\ ${ }^{1}$ Dipartimento del Museo di Paleobiologia e dell'Orto Botanico, Università degli Studi di Modena e Reggio Emilia, 41100 Modena, Italia, \\ $<$ ferretti@unimore.it>, <serpagli@unimore.it> and ${ }^{2}$ Institute of Geology AS CR, Rozvojovà 135, Praha 6 Suchdol 16502, Czech Republic, \\ $<$ storch@gli.cas.cz $>$
}

\begin{abstract}
Problematic phosphatic elements are reported for the first time from Bohemia, Czech Republic, and are attributed to Eurytholia bohemica n. sp. Similar mineralized elements, interpreted as sclerites, were known only in a very narrow interval from Middle-Late Ordovician beds bordering the Iapetus Ocean. This new report comes from the Silurian and Early Devonian and provides a significant range extension for these Problematica as well as an enlargement of their geographic extent. Comments open new perspectives in the interpretation of these elements.
\end{abstract}

\section{INTRODUCTION}

$\mathrm{T}$ HE PRINCIPAL biostratigraphic subdivision of the Silurian and Lochkovian strata in Bohemia is based upon increasingly elaborate graptolite and conodont biozonation. A joint project is underway for the precise calibration of conodont and graptolite biozonation in specific intervals of the Silurian (responsibles, ES and PŠ). Within this study, detailed resampling of some definite levels in famous sections of the Prague Basin (Beroun, Butovice, Hýskov, Kosov Quarry, Amerika Quarry, Lodenice-Černidla, Mušlovka Quarry, Požáry, U Topolů, Všeradice), where both conodont- and graptolite-rich layers are present, has been recently performed in several field seasons. Samples have been processed with the standard conodont preparation technique using formic or acetic acid and residues concentrated with sodium politungstate. The enigmatic phosphatic elements described below were picked from the heavy fraction of several levels, either from Silurian or Lower Devonian beds. In addition, a collection of these plates, made by one of us (ES) in the Barrandian in 1983, has been included in this study.

Similar small "hat-like" phosphatic plates of unknown origin were reported by Sutton et al. (2001) from the Ordovician of the Iapetus Ocean, specifically from South Wales, United Kingdom (12 specimens), Alabama, USA (nine specimens), Dalarna, Sweden (two specimens), and Estonia (one specimen). All the elements came from a very narrow stratigraphic interval of the Middle-Late Ordovician (Pygodus serra and P. anserinus conodont zones). The plates were attributed to two species of Eurytholia Sutton et al., 2001, and interpreted as dorsal dermal sclerites belonging to an animal of uncertain affinity. A provisional reconstruction of the scleritome was attempted, as a dorsoventrally flattened animal having sclerites arranged in sublongitudinal rows (Sutton et al., 2001, fig. 4).

\section{GEOLOGICAL SETTING}

Several-kilometers-thick Cambrian to Middle Devonian deposits, unmetamorphosed and weakly tectonized by the Variscan cycle, unconformably overlie Neoproterozoic basement in the Barrandian area of the Bohemian Massif (Chlupáč et al., 1998).

In the Early Ordovician, a northeast-southwest-trending Prague Basin began to subside in axial parts of the Barrandian (Havlíček, 1981; Chlupáč et al., 1998). In the earliest Silurian, the Ordovician shelfal, pelitic to psammitic sedimentation was replaced by hemipelagic black graptolitic shales. Depositional settings varied from foreslope to deep shelf/basin. In the middle Wenlock and Ludlow, rarely in the middle Llandovery, several volcanic centers produced basalt lavas, hyaloclastites, and tuffs. Basaltic volcanoes were elevated high above the anoxic basin floor and were fringed by shallow-water biodetrital limestones (Havlíček and Štorch,
1990). The Ludlow Series of the Prague Basin (Fig. 1) is represented by the Kopanina Formation-a sequence of platy, micritic (Butovice bed 10; Fig. 2), and biodetrital, richly fossiliferous limestones (Kosov samples 3, J, L; Amerika Quarry sample 3; Mušlovka Quarry samples A, B, C; Požáry sample 1; Fig. 2) interbedded with shales. Thick-bedded bioclastic brachiopod and cephalopod limestones (Mušlovka Quarry beds 33a-b and 33h-i; Fig. 2) occur particularly in the middle part and, once more, in the uppermost part of the formation (Kříž, 1998). Tuffaceous bioclastic limestones derived from local crinoidal-coral biostromes deposited in the vicinity of volcanic highs in the lower part of the Kopanina Formation. The Požáry Formation of Přídolí age is composed of platy micritic and biomicritic limestones with shaly interbeds and deposited largely under deeper, open-shelf conditions (Chlupáč et al., 1998). Former volcanic highs were capped with shallow-water, crinoidal grainstones. Massive biodetrital limestone with cephalopods and pelagic crinoids is developed in the uppermost part of the unit and in the lower part of the succeeding Lower Devonian Lochkov Formation (U Topolů bed 14; Fig. 2) (Chlupáč et al., 1972). In the Early Devonian, crinoidal limestones, calciturbidites, nodular, and also reefal types gained prevalence.

\section{MATERIAL}

About 400 problematic phosphatic plates were recovered from six Bohemian sections (Butovice, Kosov Quarry, Amerika Quarry, Mušlovka Quarry, Požáry, and U Topolů; Fig. 1). All samples were precisely constrained biostratigraphically using conodonts. Five distinct Silurian conodont zones (Ludlow) and one Devonian (Lochkovian) conodont zone were documented (Fig. 2). All stratigraphic intervals sampled for conodonts within the project are in Ludlow and Lochkovian sediments and produced phosphatic plates. It is therefore probable that other Silurian and Devonian beds might be discovered in Bohemia or elsewhere, thus giving a continuous stratigraphic record of these elements.

Phosphatic plates recovered from Bohemia occur in variable quantities, apparently not strictly related to the weight of processed material. The number of plates recovered from the same section in the Kosov Quarry (Štorch, 1995) ranges from a sole specimen (sample L: $5.6 \mathrm{~kg}$ of processed material) to three elements (sample J: $6.7 \mathrm{~kg}$ ) or 14 plates (sample 3: $4.9 \mathrm{~kg}$ ) and reaches up to 284 elements in the sample Mušlovka Quarry A (5.4 kg) (Fig. 2).

Plate dimensions range between $0.3 \mathrm{~mm}$ and $2 \mathrm{~mm}$ and their color varies from amber to black in massive specimens. If compared with conodonts, plates share the same C.A.I. 5 (Color Alteration Index) except of Kosov, where conodont elements have a slightly lower C.A.I. (3-4). Preservation of Silurian material is 

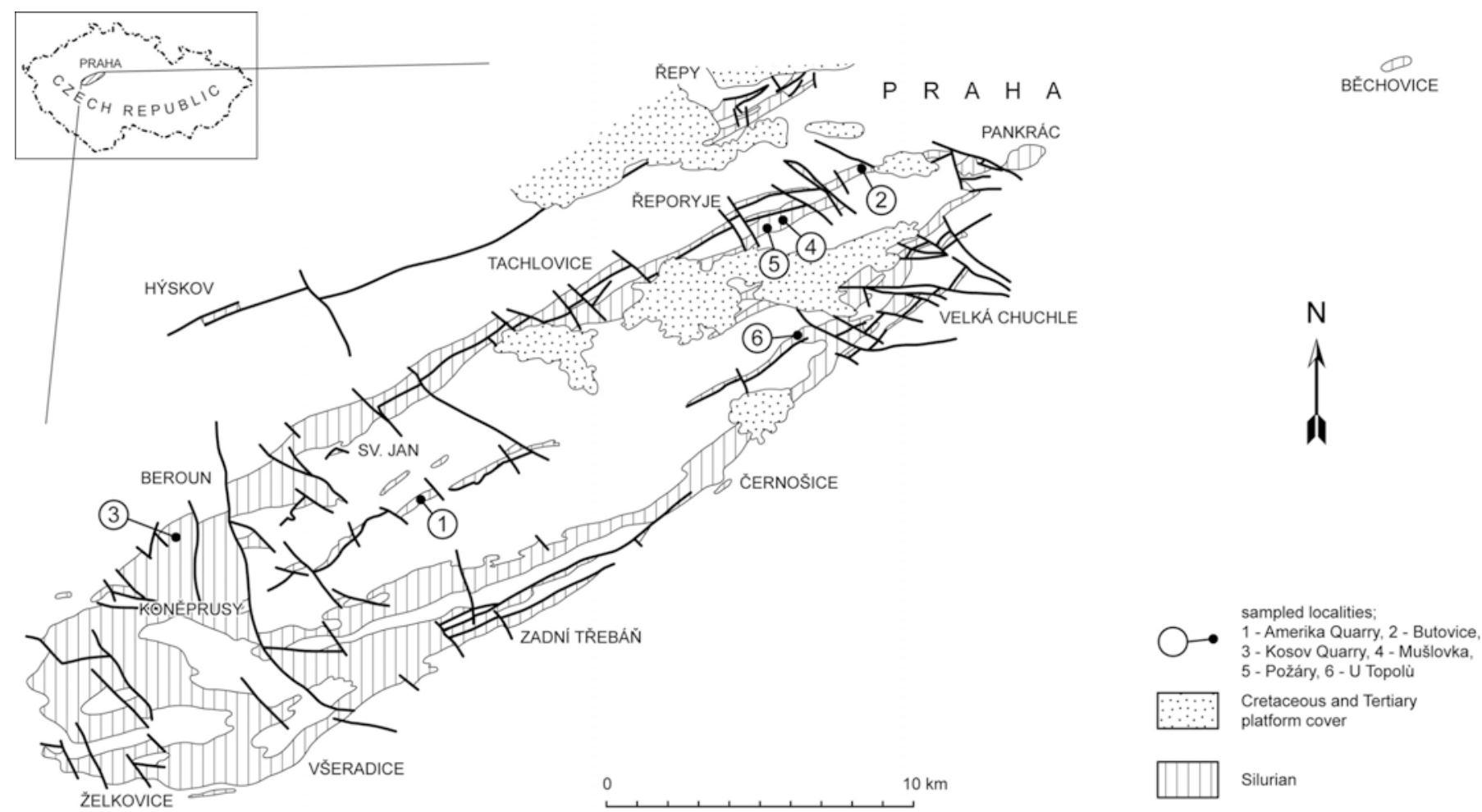

FIGURE 1 -Outcrop of Silurian rocks in Bohemia, showing sample localities.

good. Early Devonian elements are, on the contrary, poorly preserved. Detailed SEM observation of the outer surface revealed no significant ornamentation patterns or growth lines. Peripheral striae were observed along the margin of a single specimen. Rare angular pores ( $2 \mu \mathrm{m}$ in diameter) are present distally and apically (Fig. 3.8c).

In addition, the electron microscope investigation confirmed the remarks given by Sutton et al. (2001) on the shell structure. Phosphatic plates are composed of two clearly separated distinct layers (Fig. 4.10). The outer (dorsal) layer, $100 \mu \mathrm{m}$ thick, is apparently homogeneous and massive in unetched specimens (Fig. 4.9) and appears thicker than the corresponding one observed in Eurytholia prattensis Sutton, Holmer, and Cherns, $2001(20-40 \mu \mathrm{m})$. An inner (ventral) reticulated layer (Fig. 4.10) develops along all the inner surfaces (Fig. 4.12b), with a $2 \mu \mathrm{m}$ hole diameter of the "net-like" pattern. A similar ornamentation was described in the "laminated ventral secondary layer of variable thickness" of a single specimen of E. prattensis Sutton et al. (2001, p. 1), having a hole diameter of $5 \mu \mathrm{m}$. Some shell margins expose a shell lamination which might be confirmed only with a detailed study of the shell ultrastructure.

A combination of X-rays, Gandolfi camera, and EDAX analysis revealed a shell composition of calcium phosphate. It appears to be primary phosphatization since no other phosphatized fossils have been found with the fauna. Analysis of the outer layer also showed a minor presence of iron, while a fluorine enrichment was detected in the inner reticulated layer. It is noteworthy that any calcareous layer that may have been present would have been destroyed by lab processing.

\section{SYSTEMATIC PALEONTOLOGY}

The material described in this paper has been deposited at the Paleontological Museum of the "Dipartimento del Museo di Paleobiologia e dell'Orto Botanico" of the University of Modena and Reggio Emilia (IPUM).
We follow the orientation proposed by Sutton et al. (2001) for the description of the phosphatic elements.

Genus Eurytholia Sutton, Holmer, and Cherns, 2001

Type species.-Eurytholia prattensis Sutton, Holmer, and Cherns, 2001.

Diagnosis (slightly emended from Sutton et al., 2001).-Plates phosphatic, small, and transversely ovoid, symmetrical or subsymmetrical about transverse and longitudinal axes. Transverse profile subtriangular, formed by high longitudinal ridge positioned medially or submedially; lateral slopes of ridge concave. Longitudinal profile subsemicircular with sublinear anterior and posterior slopes. Ventral surface of concave plate thickened somewhat at anterior and posterior margins. Shell structure consisting of homogenous dorsal primary layer and laminated ventral secondary layer of variable thickness. Dorsal surface lacking ornamentation and growth lines.

\section{EURYTHOLIA BOHEMICA new species Figures 3, 4}

Diagnosis.-Elliptical plates having a linear or slightly curved median, submedian, or marginal ridge. A well-defined girdle with an inner furrow runs all along the margins. Wide basal cavity expands to the apex of the ridge.

Description. - Great variability in shape, size, and other main morphological features typifies our material (even within the same sample). Plate margins linear to curved. General outline transversally and longitudinally symmetrical to asymmetrical. The most common plate type (Fig. 3.8a, 3.8b) elliptical, longitudinally asymmetrical, with a ridge in eccentric position in relation to lateral margins. Long, linear anterior and posterior margins. Plate maximum length in a variable position, in some specimens corresponding to the plate ridge axis. Plate ridge perpendicular to oblique with respect to long margins. Longitudinal profile of ridge frequently asymmetrical, with highest point in a marginal position 


\begin{tabular}{|c|c|c|c|c|}
\hline LOCALITY & BED & SAMPLE & PLATES & AGE (Conodont Zone) \\
\hline BUTOVICE Na brekvici 584 & 10 & & 1 & Ludlow (K. crassa Zone) \\
\hline \multirow{3}{*}{ KOSOV } & & 3 & 16 & Ludlow (Pol. siluricus Zone) \\
\hline & & J & 3 & Ludlow (Pol. siluricus Zone) \\
\hline & & $\mathrm{L}$ & 1 & Ludlow (Pol. siluricus Zone) \\
\hline AMERIKA QUARRY & & 3 & 1 & Ludlow (Pe. latialata Zone) \\
\hline \multirow{5}{*}{ MUŠLOVKA QUARRY } & & A & 284 & Ludlow (lower part of Pol. siluricus Zone) \\
\hline & & $\mathrm{B}$ & 2 & Ludlow (mid K. crassa-mid A. ploeckensis Zone) \\
\hline & & $\mathrm{C}$ & 2 & Ludlow (?Pol. siluricus Zone) \\
\hline & $33 a-b$ & & 21 & Ludlow (Oz. snajdri Zone) \\
\hline & $33 \mathrm{~h}-\mathrm{i}$ & & 5 & Ludlow (Oz. crispa Zone) \\
\hline POŽÁRY & & 1 & 71 & Ludlow (lower part of Pol. siluricus Zone) \\
\hline U TOPOLŮ & 14 & & 9 & Early Devonian (Pe. pesavis Zone) \\
\hline \multicolumn{3}{|c|}{ Total number of phosphatic plates $=$} & 416 & \\
\hline
\end{tabular}

FIGURE 2-Age and abundance of phosphatic plates in the Bohemian samples. Conodont biozones mostly refer to Corradini and Serpagli (1999).

(Fig. 4.1, 4.6). Height and width of median ridge strongly variable and independent from general dimensions of the plate. The ridge may be, in fact, large (Fig. 3.4) or slim (Fig. 3.2), rounded or sharp, or having a small apical depression (Fig. 4.11b). The ridge is sometimes apically worn (Fig. 3.11b) but no true abrasions, scratches, or cuts have been observed along the ridge that might be convincingly attributed to in vivo damage. Lateral slopes of ridge symmetrical to asymmetrical in transverse view. Plate halves often dorsally bent (Fig. 4.2).

Plate girdle is delimited by two well-defined thickened margins (Figs. 3.3, 3.5, 4.8). A linear inner furrow runs in between all along the plate. The upper margin of the girdle may protrude outside the basal cavity margin (Fig. 3.9).

Rare pores $(2 \mu \mathrm{m}$ in diameter) with a geometric outline (Fig. $3.8 \mathrm{c})$ may occur with no preferential arrangement either in the apical or distal part of the plates.

The wide basal cavity expands deeply below the ridge, and in plates having a marginal ridge the cavity is edged on one side by the ridge wall and on the other by a wide platform (Fig. 3.10).

A more rounded aspect characterizes some subcircular plates (Fig. 3.7), longitudinally and transversally symmetrical, having nonlinear anterior and posterior margins and lateral margins not easily detectable from the former. Others have, however, a subrectangular profile (Fig. 3.1, 3.2).

One specimen reveals a hole with circular outline on one side of the plate, and with perpendicular walls (Fig. 4.4). Excavations and predatory perforations are reported in various phosphatic groups such as Cambrian shells (Conway Morris and Bengtson, 1994), Ordovician brachiopods (Holmer, 1989), and conodonts (Müller and Nogami, 1972).

Two plates (Fig. 4.12a) were found fused together. Similar clusters are common in conodonts and represent elements fused together by diagenetic minerals which may (e.g., Nicoll, 1985; Nicoll and Rexroad, 1987) or may not (e.g., Nowlan, 1979; Dzik and Drygant, 1986) retain the functional orientation they had in the living animal (Purnell and Donoghue, 1998). The rocks from which these plates come are mainly bioclastic packstones, rich in trilobites and echinoderm fragments, suggesting energy for transport which would have dissociated unfused elements of an assemblage.

Etymology.-From Bohemia.

Type.-Holotype, IPUM 27845, Figure 3.8a, 3.8b. Sample Kosov 3, Kopanina Formation, Kosov Quarry, Ludlow (Polygnathoides siluricus Zone).

Other material examined.-Four hundred fifteen elements.

Occurrence.-Silurian (Ludlow) and Devonian (early Lochkovian) of Bohemia, Czech Republic.

Discussion.-The Bohemian specimens appear bigger than the older reports, having a maximum width of $2 \mathrm{~mm}$ (compared to $1.2 \mathrm{~mm}$ in E. prattensis and E. elibata Sutton, Holmer, and Cherns, 2001). The Ordovician material bears anterior and posterior margins often thickened in "rolls," extending possibly also to lateral margins. The Bohemian material reveals, on the contrary, a well-defined girdle, bordered by two margins, running all along the entire plate border with a more or less regular thickness.

FIGURE 3-Scanning electron micrographs of Eurytholia bohemica n. sp. 1, Upper view of IPUM 27838, Mušlovka Quarry 33 h-i, $90 \times .2 a, 2 b$, Upper and lateral views of IPUM 27839, Mušlovka Quarry A, 90×. 3, Lower-lateral view of IPUM 27840, Kosov 3, 130×. 4, Upper view of IPUM 27841, Mušlovka Quarry A, 90×. 5, Lateral view of IPUM 27842, Požáry 1, 70×. 6, Upper view of IPUM 27843, Mušlovka Quarry A, $105 \times$. 7, Upper view of IPUM 27844, Kosov L, 90×. $8 a, 8 b$, Upper and lateral views of holotype, IPUM 27845, Kosov 3, 90×; $8 c$, detail of an angulous pore, 2,200×. 9, Inner view of IPUM 27846, Mušlovka Quarry A, 105×. 10, Inner view of IPUM 27847, Požáry 1, 105×. 11a, Upper view of IPUM 27848 , U Topolů, $105 \times ; 11 b$, detail of the ridge, $370 \times$. 


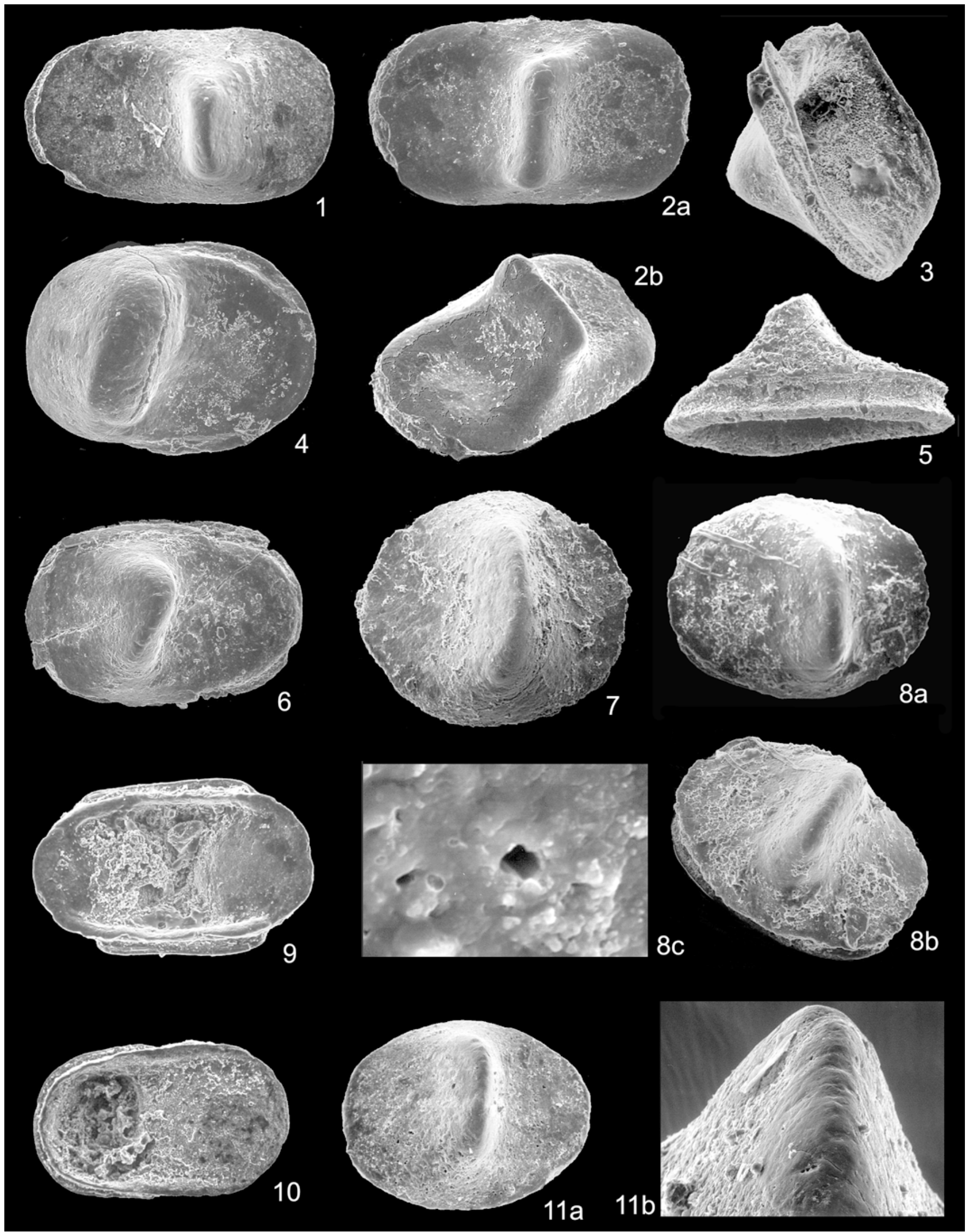




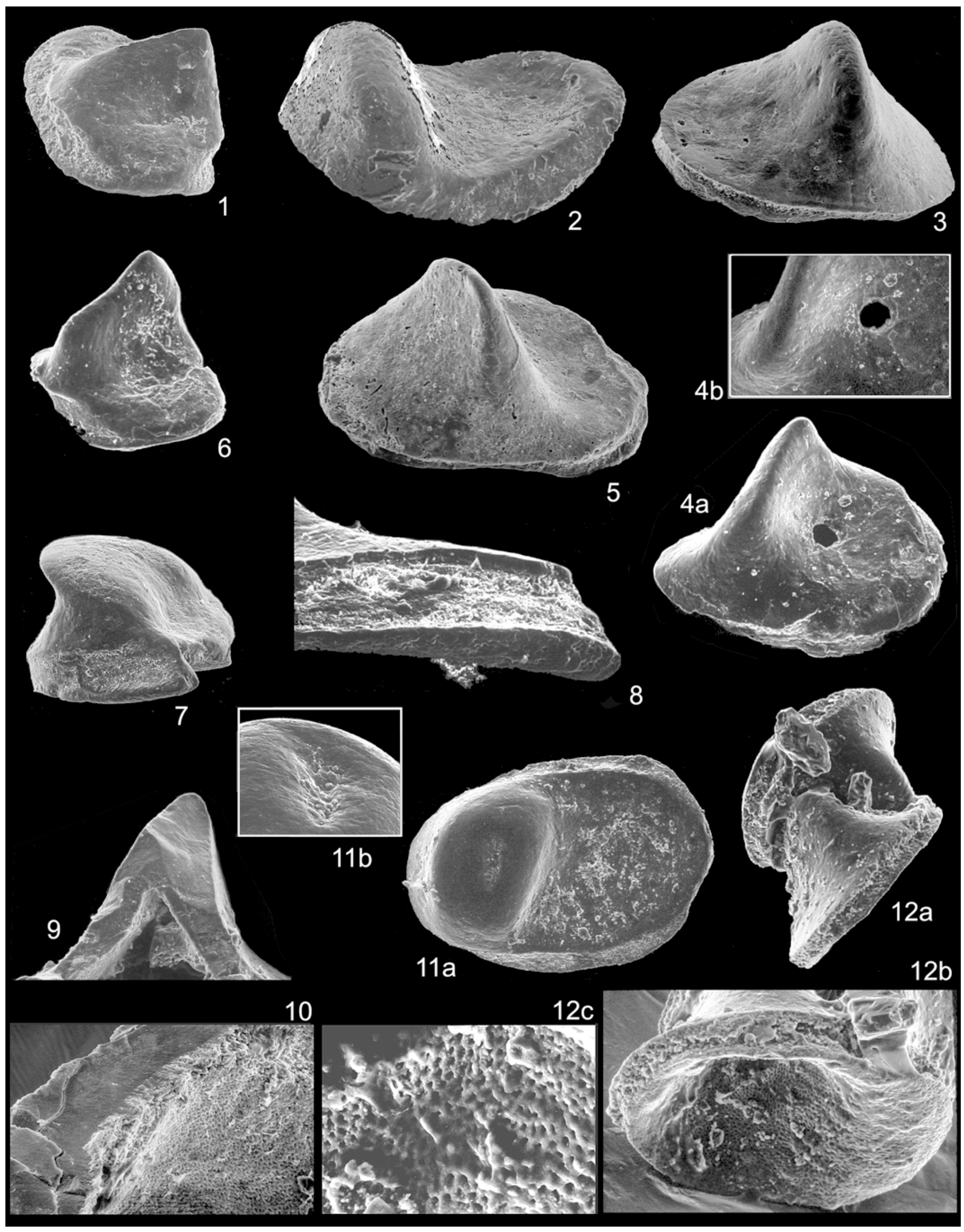


E. bohemica differs from E. prattensis in lacking the median indentation ("waist") in anterior and posterior margins, having median length often representing maximum plate length, sometimes even expanding outwards. E. bohemica differs from $E$. prattensis in bearing a more rounded and less angular general aspect. E. bohemica differs from E. elibata in having no median arching of posterior and anterior margins above the resting plane.

\section{CONCLUSION}

Sutton et al. (2001) carefully analyzed possible affinities of these Problematica and regarded the phosphatic plates as disarticulated skeletal elements of a scleritome possessing only one sclerite morphotype. Phosphatic elements were possibly arranged in soft tissue (presumably chitinous) and exerted a protective function.

Our observations of the Bohemian material confirmed many of the morphological and structural features already pointed out by previous authors. In addition, small pores have been observed. Moreover, compared to the simple thickening of the anterior and posterior margins of earlier reports, Eurytholia bohemica n. sp. bears a peculiar girdle along all margins which appears to be a more sophisticated site for attachment or insertion into the animal's soft tissue.

The possible evidence of predation in the Bohemian material, even if from a sole specimen, could support a protective role for these plates. In spite of that, a predator could have more easily attacked in unprotected parts of the body (such as plate interspaces).

The Bohemian material considerably enlarges the geographic extent and significantly extends the range of these Problematica, which appear to be a common constituent of the late SilurianEarly Devonian fauna in Bohemia and possibly elsewhere. A recent finding of E. bohemica from the late Silurian of the Austrian Carnic Alps (AF and ES personal obs.) corroborates the idea. The stratigraphical range of Eurytholia was a period when the earliest vertebrates were evolving. The possible affinity with the vertebrates needs to be fully explored, mainly by histological analysis.

\section{ACKNOWLEDGMENTS}

Special thanks to E. Galli, who assisted us with the mineralogic analysis. Thanks are extended to C. Gentilini for SEM support and A. Vescogni for help with figures. S. Bengtson and M. D. Sutton are thanked for their input in improving the paper. The early sclerites collected in 1983 by ES were recovered from samples jointly collected with J. Kř́̌ž, who is deeply acknowledged. Research support was provided through grants within the project 23/ES 1, "Fossils as time indicators: Integrated conodont-graptolite biostratigraphy of selected Lower Palaeozoic sections of Czech Republic (Barrandian area) and Italy (Carnic Alps and Sardinia)" and the PRIN project "The end and the beginning: Loss and recoveries from the end-Ordovician mass extinction in North Gondwana."

\section{REFERENCES}

Chlupéč, I., H. JAeger, AND J. Zikmundová. 1972. The Silurian-Devonian Boundary in Barrandian. Bulletin of Canadian Petroleum Geology, 20:104-174.

Chlupáč, I., V. HavlíčeK, J. KŘíž, Z. KuKal, AND P. ŠToRCh. 1998. Palaeozoic of the Barrandian (Cambrian-Devonian). Czech Geological Survey, Prague, 183 p.

Conway MorRIs, S., AND S. Bengtson. 1994. Cambrian predators: Possible evidence from boreholes. Journal of Paleontology, 68:1-23.

CoRradini, C., AND E. SERPAGLI. 1999. A Silurian conodont biozonation from late Llandovery to end Př́ídolí in Sardinia (Italy), p. 255-273. In E. Serpagli (ed.), Studies on Conodonts: Proceedings of the Seventh International Symposium on Conodonts. Bollettino della Società Paleontologica Italiana, 37 (1998).

DzIK, J., AND D. DRYGANT. 1986. The apparatus of panderodontid conodonts. Lethaia, 19:133-141.

HAVLÍČEK, V. 1981. Development of a linear sedimentary depression exemplified by the Prague Basin (Ordovician-Middle Devonian, Barrandian area-central Bohemia). Sborník Geologických Věd, Geologie, 35: $7-48$.

HAVlíčEK, V., AND P. ŠTORCH. 1990. Silurian brachiopods and benthic communities in the Prague Basin (Czechoslovakia). Rozpravy Ústředního Ústavu Geologického, 48:1-275.

HOLMER, L. E. 1989. Middle Ordovician phosphatic inarticulate brachiopods from Västergötland and Dalarna, Sweden. Fossils and Strata, 26: $1-172$.

KŘíž, J. 1998. Recurrent Silurian-lowest Devonian cephalopod limestones of Gondwanan Europe and Perunica, p. 183-198. In E. Landing and M. E. Johnson (eds.), Silurian Cycles: Linkages of Dynamic Stratigraphy with Atmospheric, Oceanic and Tectonic Changes. New York State Museum Bulletin, 491.

MÜlLER, K. J., AND Y. NOGAMI. 1972. Entöken und Bohrspuren bei den Conodontophorida. Paläontologische Zeitschrift, 46:68-86.

NiCOLL, R. S. 1985. Multielement composition of the conodont species Polygnathus xylus xylus Stauffer, 1940 and Ozarkodina brevis (Bischoff \& Ziegler, 1957) from the Upper Devonian of the Canning Basin, Western Australia. BMR Journal of Australian Geology \& Geophysics, 9:133-147.

Nicoll, R. S., AND C. B. ReXROAD. 1987. Re-examination of Silurian conodont clusters from northern Indiana, p. 49-61. In R. J. Aldridge (ed.), Palaeobiology of Conodonts. British Micropalaeontological Society Series. Ellis Horwood Limited, Chichester.

Nowlan, G. S. 1979. Fused clusters of the conodont genus Belodina Ethington from the Thumb Mountain Formation (Ordovician), Ellesmere Island, District of Franklin. Current Research, Pt. A. Geological Survey of Canada Paper, 79-1A:213-218.

Purnell, M. A., AND P. C. I. Donoghue. 1998. Skeletal architecture, homologies and taphonomy of ozarkodinid conodonts. Palaeontology, 41:57-102.

ŠTORCH, P. 1995. Upper Silurian (upper Ludlow) graptolites of the $N$. inexpectatus and N. kozlowskii biozones from Kosov Quarry near Beroun (Barrandian area, Bohemia). Bulletin of the Czech Geological Survey, 70:65-89.

SutTon, M. D., L. E. Holmer, AND L. Cherns. 2001. Small problematic phosphatic sclerites from the Ordovician of Iapetus. Journal of Paleontology, 75:1-8.

ACCEPTED 9 June 2005

FIGURE 4-Scanning electron micrographs of Eurytholia bohemica n. sp. 1, Lateral view of IPUM 27849, Požáry 1, 115×. 2, Lateral view of IPUM 27850, Požáry $1,125 \times$. 3, Lateral view of IPUM 27851, Butovice, 100×. 4a, Lateral view of IPUM 27852, Mušlovka Quarry A, 100×; 4b, detail of plate hole in upper view, 100×. 5, Lateral view of IPUM 27853, U Topolů, 75×. 6, Lateral view of IPUM 27854, Mušlovka Quarry A, 105×. 7, Lateral view of IPUM 27855, Mušlovka Quarry A, 90×. 8, Lateral view of girdle of IPUM 27856, Mušlovka Quarry A, 190×. 9, Lateral view of broken specimen IPUM 27857, illustrating detail of the wall, Mušlovka Quarry A, 210×. 10, Detail of shell structure of IPUM 27858, illustrating double-layered structure, U Topolů, 280×. 11a, Upper view of IPUM 27859, Mušlovka Quarry A, 105×; 11b, detail of plate ridge in lateral view $(300 \times) .12 a$, Lateral view of two fused plates, IPUM 27860, Kosov 3,130×; 12b, inner-lateral view of the cavity, showing a regular netlike pattern, $220 \times ; 12 c$, detail of the net structure, $800 \times$. 